DOI: $10.14394 /$ edufil.2020.0010

\title{
Dyskusja o religii i magii
}

na podstawie notatek $\mathrm{z}$ lektur: Benjamina Constanta, O czuciu religijnym, i Bronisława Malinowskiego, Magia, nauka i religia ${ }^{1}$

\author{
Paweł Okołowski \\ (Uniwersytet Warszawski, Wydział Filozofii)
}

Konwersatorium: Wybrane zagadnienia z filozofii człowieka i filozofii wartości, dr hab. Paweł Okołowski, semestr letni 2019/2020, Wydział Pedagogiki UW.

Anna Żeromska pisze w swojej notatce: Istnieją różne religie i nie uważam, że każda $\mathrm{z}$ nich jest dobra. Niektóre z nich w imię Boga zabijają ludzi, próbują się wzmocnić, pokazać siłę. Tylko po co? Skoro jakaś religia miałaby być silna, to przez liczbę osób w nią wierzących, a nie liczbę ofiar. Niestety religia, która miała być dobrem, wszczyna spory.

Paweł Okołowski: To prawda, religie nie są sobie równe - głównie ze względów moralnych, co wynika, m.in., z różnych wizji człowieka w nich zawartych. Nie ma natomiast paradoksu, na który Pani wskazuje. Populacja ludzka jest stale podzielona na rywalizujące wspólnoty - i to się nigdy nie zmieni. Religie (ich formy) to wspólnoty, więc walczą o dominację. Niektóre religie się w tej walce powściągają (jak chrześcijaństwo czy buddyzm), inne - nie (jak islam). Ale walka stale się

1 B. Constant, rozdz. I: O czuciu religijnym, w: tegoż, O religii, przeł. S. Kruszyńska, PWN, Warszawa 2008, s. 27-47. B. Malinowski, Magia, nauka i religia, w: tegoż, Dzieła, t. 7: Mit, magia, religia, tł. B. Leś, D. Praszałowicz, PWN, Warszawa 1990, s. 368-389, 429-445. 
toczy. Po co? A po co są dwa bieguny w magnesie? Taki jest świat i już. Religia nie wywołuje sporów, tylko jedne religie mogą wzmagać antagonizmy między ludźmi, a inne - hamować (choć nie do zera). Źródła antagonizmów tkwią w osobach, w ich DNA. Społeczeństwo może osobnicze skłonności jedynie modulować, a nie likwidować czy powoływać.

Małgorzata Sieńkowska mówi: Człowiek jako jedyny w przyrodzie ma wolną wolę. Może sam obrać swoje życie, jak ono się potoczy i kim w życiu będzie. Zwierzęta już od urodzenia mają tylko dwie funkcję: albo są ofiarami, albo drapieżnikami.

P.O.: Zwierzęta są zdeterminowane w działaniach tylko (ale twardo, ściśle) przyrodniczo, a my - przyrodniczo i duchowo. Te dwie niezależne determinacje stwarzają nam jakieś pole wolności (tzw. wolną wolę). Ta nasza wolna wola to jeden z największych problemów filozoficznych. Na czym ona polega? Jasne, że nie na tym, iż mogę w danej chwili coś zrobić albo tego nie zrobić. Jestem bowiem zdeterminowany przez wychowanie, które odebrałem, przez moje wrodzone talenty i brak innych talentów itp. Nie mogę wiec „obrać swojego życia” dowolnie, np. zostać malarzem, kiedy urodziłem się jako beztalencie plastyczne. Mogą mi się przytrafić jedynie różne wspólnoty, które mną pokierują (rozmaitymi zasadami życia); do którejś się włączę. To włączenie wszak też ode mnie nie zależy. To wspólnota nas wybiera, nie my ją. Na tym polega nasz „wolny wybór”. Przecież katolicyzmu albo komunizmu nikt sobie nie wybiera, tak jak marki samochodu. To się samo jakoś staje (ten akces do wspólnoty).

Aleksandra Dąbrowska: Jeśli chodzi o talenty, to mogę się zgodzić. Jeżeli jednak chodzi o inne aspekty życia człowieka, to będę obstawała przy wolnej woli. Człowiek może zmienić wyznanie. Mimo że został wychowany w danej kulturze, może zmieniać i formować swoje życie. Może nie jest to łatwe, ale możliwe.

Emilia Staszewska: Czy takie, jak Pan przedstawia, pojmowanie otaczającej nas rzeczywistości nie jest $\mathrm{w}$ jakimś stopniu powieleniem wiary $\mathrm{w}$ fatum $\mathrm{z}$ czasów starożytnych filozofów? Czy oznacza, że układ podejmowanych decyzji przez ludzi z wolną wolą tworzy ograniczającą nas rzeczywistość? Czy nasza wolna wola jest ograniczona? 
P.O.: Oczywiście, że ograniczona. Wolna wola to nie dowolność. Na każdą osobę działa fatum - jej genów, jej nabytych obyczajów, jej epoki. Tak twierdził, na przykład, Stanisław Lem - fatalista niestarożytny („powielający wszak pogląd starożytnych"). Poza tym każde ludzkie życie kształtowane jest przez przypadek, zdarzenia nieprzewidywalne. Między koniecznością a przypadkiem mieści się jakoś nasza wolna wola, zawsze możemy „iść za rozumem”, szympansy nie mogą. My - możemy...

I jeszcze Małgorzata Sieńkowska pisze: Raczej bym podkreśliła nieśmiertelność duszy człowieka, jako element, który sprawia, że wierzymy w coś bądź nie. Ciało człowieka nie ma świadomości jak dusza i uważam, że dusza jest ważniejsza. Ciało jest skazane na zniszczenie - i proces ten cały czas trwa, dążąc do śmierci. Dusza jednak cały czas się kształtuje i rozwija, nie ma momentu, w którym zaczyna umierać.

P.O.: Jak to, dusza nie umiera? A alzheimer, śpiączka, śmierć mózgowa? Dusza też się „Zwija”. Idea nieśmiertelności duszy indywidualnej to religijna idea staroegipska, obecna też choćby w chrześcijaństwie. Ale nie u starożytnych Żydów, nie u Chińczyków, nie u Hindusów czy w buddyzmie. Co innego nieśmiertelność duszy, co innego wieczność duchowych wartości. Można być ateistą i to drugie uznawać.

Emilia Staszewska powiada: [...] Człowiek może sprzeciwiać się formie religii mimo potrzeby „czucia religijnego”. Zaciekawiło mnie pytanie, które Constant postawił sam sobie, o istnienie „czucia religijnego niezależnego od religii”. Wydaje mi się, że chodzi o istotę potrzeby religii niezależnie od jej konkretnej formy. Jednak autor neguje, aby taka możliwość wchodziła w grę.

Publikacja Benjamina Constanta O religii zainteresowała mnie i skłoniła do wielu refleksji. Autor ciekawie opisał potrzebę religijną jako naturę człowieka. Zastanawia mnie jednak: co z ludźmi, którzy odrzucają idee istnienia sił nadprzyrodzonych?

P.O.: „Czucie religijne” to religijność, skłonność wrodzona człowieka do zachowań religijnych w ogóle. Szympansy takiej nie mają (w DNA). Co innego zaś „forma religijna”, w którą to czucie się obleka (i przejawia). U kogoś w katoli- 
cką, a u kogoś - w formę komunistyczną. Czucia religijnego bez formy (społecznej) być nie może. U oseska tylko (wtedy już czucie jest, ale uśpione). Natomiast ludzie, którzy odrzucają idee sił nadprzyrodzonych, nie są bezreligijni. Wierzą oni zawsze w jakiś Inny Świat, choćby ten, który nastanie w przyszłości, po ich śmierci (nieskończone przedłużanie życia przez medycynę, raj komunizmu itp.). Na przykład Chińczycy wierzą w nieskończone trwanie rodu czy rodziny, bez żadnych sił nadprzyrodzonych.

Aleksandra Walczak: Uważam, że natura człowieka jest uogólnieniem dotyczącym wszystkich ludzi, jednakże każdy z nas ma inny temperament, inny charakter, a one determinują wiarę. Czy ludzie odrzucający idee istnienia sił nadprzyrodzonych nie wierzą w nic? Moim zdaniem każdy człowiek w coś wierzy.

P.O.: Z tym „uogólnieniem” to należy rzecz doprecyzować: natura ludzka to nie jest ogół cech czy skłonności przysługujących wszystkim ludziom, ale ogół typów skłonności, które jakimkolwiek ludziom przysługują. Egoizm jest częścią natury ludzkiej, choć wiadomo, że bywają nie-egoiści; diabelstwo też jest, chociaż większość ma może dobrą wolę. Natura ludzka to są możliwości zachowań naszego gatunku, osobniczo u jednych występujące (w różnym stopniu), u innych wcale. To samo z „czuciem religijnym”: większość je ma, ale bywają też (rzadko) bezreligijni.

Emilia Staszewska: W jaki sposób ideologię, np. komunizmu, można rozumieć jako nową formę religijną?

P.O.: W sposób bardzo łatwy: dostarcza ona wyznawcom nadziei na to, co będzie po osobniczej śmierci. Ponadto jak każda religia, przejawia kult, określony sposób życia wyznawców i dysponuje ich organizacją (niekiedy zhierarchizowaną i potężną!). Albo jak mawiał Rudolf Otto: stoi za nią „Tajemnica - wzniosła, przykuwająca i straszna”. We Lwowie podczas rosyjskiej okupacji pytano dzieci w szkole - „czy wierzą w Boga, czy w Stalina?”. Za „Stalina” dostawały cukierka (wedle Arthura Allena). 
Agata Mrowińska pisze: Jeśli uznamy, że religia jest częścią człowieka, to myślę, że tak naprawdę, dopóki coś nie zniszczy całego człowieka (o ile jest taka możliwość), nic, co pochodzi z zewnątrz, nie zagraża religii.

P.O.: Może ulec zniszczeniu jakaś religijna forma (np. chrześcijaństwo), ale w jej miejsce zawsze pojawi się inna. Tak myślał Constant: że potrzeba religii jest w człowieku stała („czucie religijne”). A o jaką możliwość „zniszczenia całego człowieka" chodzi? O zniszczenie gatunku? Jeżeli zostaną same zwierzęta, religii nie będzie. Jeśli zastąpi ludzi inny gatunek istot rozumnych, myślę - że wytworzy własne religie (tak sądził Lem).

Małgorzata Sieńkowska: Człowieka, niestety, bardzo łatwo zniszczyć, choćby torturami. Najczęściej jednak niszczy się człowieka psychicznie. To najłatwiejszy sposób, by był on posłuszny.

P.O.: Zgoda, ale nie widzę powodu, dla którego tortury fizyczne czy psychiczne miałyby osobę pozbawić religijności w ogóle. Jest wręcz przeciwnie. Chyba że by zniszczyć wszelką wspólnotę, pozbawić ludzi wspólnoty - tak jak to uczyniono na Kołymie, w radzieckich Gułagach. Wówczas religijność zamiera, jak w hordzie pierwotnej.

W notatce pani Joanny Gólczyńskiej czytamy: [...] W ludziach jest skłonność, która stoi w sprzeczności z ziemskimi celami, „głos duszy”, który mówi, że to wszystko jest tylko mechanizmem, a cel okazał się jedynie środkiem. Ta skłonność popycha nas do przekraczania samych siebie, skłania do nieznanego działania, oderwanego od codzienności - podkreślenie tutaj wagi uczuć. Uniwersalne czucie łączy się z religią, wiarą w nadprzyrodzone. Czucie religijne daje nadzieję na coś doskonalszego i nieograniczonego, daje nadzieję na spokój (nie da się podać ścisłej definicji).

P.O.: „Przekraczanie samego siebie” - to brzmi po Freudowsku (samorealizacja, ona wszak nie wykracza poza codzienność). „Przekraczał siebie” także Józef Stalin - w sensie już duchowym, ale diabelskim. Uczucia o niczym nie przesądzają, bo bywają dobre i złe. Uczucia zawsze towarzyszą naszej woli, każdej. Religia nie musi łączyć się z "nadprzyrodzonym”, ale musi z Innym Światem (którego nie 
ma w codzienności). Nie da się podać definicji czego? Czucia religijnego? Zawsze się da (np. czucie religijne = poruszenie duszy faktem śmiertelności), lecz nie w samej definicji rzecz - tylko w zespole twierdzeń tłumaczących świat. A takie twierdzenia tłumaczące religię, jasne, zrozumiałe, także da się podać.

Aleksandra Walczak pisze: Jeżeli religia ma swoje miejsce w głębi ludzkich dusz, to skąd sprzeciw niektórych ludzi wobec niej? Ludzie, u których budzi się ten sprzeciw, bywają najlepiej wykształceni, najbardziej godni szacunku. Oni uznają, że jedynym rezultatem rozumowania jest niepewność. W ludziach jest pierwiastek, który buntuje się przeciwko intelektualnym przeszkodom. Dlatego pojawił się opór wobec religii, w szczególności w tych wiekach, w których ludzie domagali się moralnej niezależności. Człowiek musiał wykazać się odwagą, aby przeciwstawić się najgorszej z możliwych tyranii. Czy dobrze rozumiem, że ci ludzie nie przeciwstawiali się wierze i religii samym w sobie, ale przeciwstawiali się ograniczeniom, które one nakładały? Przyczyny nieszczęść ludzkich są liczne i ludzie wszędzie szukają pocieszenia i prawie wszystkie pocieszenia są religijne. Religia jest wierną towarzyszką, niestrudzoną oraz zmyślną przyjaciółką człowieka nieszczęśliwego. Bardzo to ważne!

Joanna Sobczak: Warto jednak zauważyć, że zdarza się, że w obliczu tragedii odwracamy się od religii i nie chcemy mieć z nią nic wspólnego.

P.O.: Odwracamy się od religii dotychczas wyznawanej. I popadamy w wiarę inną. „Pustka duchowa” to nie jest próżnia doskonała, tylko obszar substytutów. Często też występują u ludzi wiary synkretyczne, łączące elementy różnych religii. Na przykład po odrzuceniu części doktryny chrześcijańskiej coś z chrześcijaństwa pozostaje, choćby sposób życia.

A sprzeciw niektórych ludzi inteligentnych i wykształconych wobec religii w ogóle bierze się z błędu poznawczego (w zakresie filozofii - bo przecież wielka nawet inteligencja nie działa równie wydajnie we wszystkich dziedzinach, inteligentny w zakresie matematyki nie musi być taki w zakresie poezji). Biorą oni za religię tylko chrześcijaństwo, buddyzm czy inne formy tradycyjne, ale nie formy nowe, jak komunizm czy scjentyzm. Ludzie zaś, którzy przeciwstawiają się religiom rygorystycznym (ograniczającym mocno wolność jednostki), sami 
reprezentują wierzenia permisywne (choć też religijne). Wierzą, że nie będzie wojen już nigdy, że kobieta nie różni się duchowo od mężczyzny itp. (wierzą w taki Inny Świat). To równie irracjonalne jak Trójca Święta, ale bardziej szkodliwe! Nie każda religia zaś jest pocieszycielką człowieka nieszczęśliwego, ale każda nieszczęśliwego z powodu śmiertelności własnej i bliskich.

Aleksandra Walczak: Nie ukrywam, że dopiero teraz, po lekturze tekstów i tej dyskusji, nabrałam przekonania, że religią jest nie tylko wiara $\mathrm{w}$ wybranego boga, ale wiara w wiele innych spraw, wartości czy ideologii. Istotną kwestią dla mnie jest przekonanie, że każdy człowiek w coś wierzy.

Karolina Poświata: Czy w tym miejscu można odnieść się nie do samej religii, tylko do instytucji, które działają w ramach religii? Wydaje mi się, że opisani przez Panią Walczak ludzie sprzeciwiać się mogą nie samej religii, tylko ludziom tworzącym instytucję, np. księżom i biskupom, ich działaniom i słowom.

P.O.: Nie ma „religii samej”, bez instytucji, nigdy. Bywają natomiast szkodliwi kapłani i szkodliwi wyznawcy. I im należy się przeciwstawiać.

Anita Prusarczyk mówi: Skłonność religijna jest sprzeczna z naszym ziemskim celem oraz naszymi zdolnościami, popycha nas do przekraczania samych siebie. Czucie religijne jest odpowiedzią na nasz poryw ku nieznanemu, którego nie jesteśmy w stanie ujarzmić. Powyższe jest dla nas zalążkiem nieśmiertelności, mimo że nasze ciało jest skazane na zagładę.

P.O.: O tym już było. Sprzeczna nie jest, dotyczy Innego Świata. „Przekraczanie samych siebie" zaś to wyrażenie bardzo niebezpieczne - można przekraczać Dekalog. Religia daje zaś możliwość przekraczania horyzontu własnego życia. I to daje pociechę, pomaga ułożyć się ze śmiercią. „Nieśmiertelność” jest tu symbolem tego, co będzie po mojej śmierci. Czegoś dobrego czy potężnego. Nie musi to być wieczne trwanie duszy.

Anita Prusaczyk: Zgadzam się, że religia daje możliwość przekraczania horyzontu własnego życia. Religia nie jest sprzeczna ze światem, lecz dotyczy Innego Świata, a nieśmiertelność jest symbolem. 
Aleksandra Dąbrowska zaś pisze: Wydaje mi się, że do „niewiary” naprawdę jest potrzebna odwaga. Bo w momencie, w którym człowiek zostaje pozostawiony sam sobie, ogarnia go pustka i beznadzieja, potrzeba mu dużo odwagi, aby żyć.

P.O.: Niewiary w co? Jedną niewiarę zastępujemy inną wiarą. Zawsze. Nigdy nie zostajemy sami, zawsze lgniemy do podobnych. Odwaga, oczywiście, jest niezbędna w przypadku wiary nowej, skazanej na masowe, społeczne potępienie. Tak było z wczesnym chrześcijaństwem i wczesnym komunizmem. Ale nie jest tak z nimi dziś. Odważni są sekciarze, choć rzadko to chwalebne.

Aleksandra Dąbrowska: Chodziło mi o niewiarę w życie po śmierci.

Małgorzata Sieńkowska: Nie potrzeba chyba aż tak „wielkiej” odwagi do niewiary. Coraz częściej ludzie odwracają się od tradycyjnej religii, jest takich coraz więcej, co świadczy nie o odwadze, a raczej o zmianie światopoglądu. Przestaliśmy bowiem postrzegać Boga jako coś, co nas trzyma przy życiu.

P.O.: Świadczy to odchodzenie głównie o zmianie stylu czy sposobu życia. Jeżeli ktoś żyje nie po Bożemu, to i w Boga nie wierzy. I nie chodzi tu o samo dopuszczanie się grzechu, ale o zlikwidowanie w ogóle kategorii grzechu („nie ma winnych, są tylko pokrzywdzeni").

Julia Bastek, już w kwestii magii (i tekstu Malinowskiego), powiada: Magia i religia nie są wyłącznie doktryną, filozofią czy też wyłącznie intelektualnym zestawem opinii. Są one sposobem zachowania, postawą pragmatyczną, zrodzoną z uczucia - rozumu - woli. Magia nigdy nie powstała, nigdy nie została stworzona ani wymyślona. Najzwyczajniej w świecie po prostu „była”. Ma ona ludzkie właściwości i stanowi pierwotne wyposażenie człowieka, które można poznać tylko dzięki tradycji. Powinniśmy postrzegać magię jako ucieleśnienie wzniosłej fantazji/nadziei, która jak dotąd była najlepszą szkołą ludzkiego charakteru.

P.O.: Skłonności magiczne to pewien segment ludzkiej woli, wrodzony. Ale uruchomiony w górnym paleolicie, kiedy ludzie posługiwali się już powszechnie językiem (więc i myśleniem). „Zawsze była” znaczy raczej jej niezmienność. Tradycja przekazuje od paleolitu te same przeświadczenia i czynności magiczne 
(zmieniają się tylko ich szaty, np. astrologów). Mors certa, hora incerta (śmierć pewna, godzina niepewna - mawiali Rzymianie, i my powtarzamy do dziś). $\mathrm{Z}$ pierwszego bierze się religia, $\mathrm{z}$ drugiego magia. Magia to „rytualizacja optymizmu” w kwestii pecha, nieszczęśliwego losu, tj. przypadku. Magia to duchowy sposób na niefart. Nadzieja i quasi-manipulacja światem - przeciw niefartowi. Czy to jest wzniosłe? I czy jest szkołą charakteru? Wątpię. Jest niezbędne, to tak. Religia zaś może być jednym i drugim.

Aleksandra Subdysiak pisze: Zarówno magia, jak i religia powstają i funkcjonują w sytuacjach stresu emocjonalnego, w przełomowych momentach życia. Dają one możliwość ucieczki z takich sytuacji, z których w istocie nie ma wyjścia. Magia ma charakter praktyczny, za główny jej cel można uznać osiągnięcie bezpośrednich rezultatów życiowych. Religia natomiast, mimo że ma charakter duchowy, to mamy $\mathrm{w}$ niej do czynienia $\mathrm{z}$ nieodwracalnymi wydarzeniami. Bardzo spodobało mi się stwierdzenie Malinowskiego, że „funkcją magii jest rytualizacja ludzkiego optymizmu", umacnianie wiary w zwycięstwo nadziei nad strachem.

P.O.: „Stresu emocjonalnego” (innego nie ma) - ale z różnych powodów. Religia - z powodu fatum śmiertelności (pewności losu w tej kwestii); magia - z powodu niepewności losu i zagrożenia nieszczęśliwym przypadkiem.

W notatce Anny Żeromskiej zaś czytamy: Tak jak w tekście wspomniano, religia trochę łączy się z magią, ponieważ tu i tam istnieją zjawiska, których nie jesteśmy w stanie wytłumaczyć. Natomiast magia łączy się też z nauką. Tylko co mamy na myśli, mówiąc o magii? Na pewno nie to, że człowiek może opanować przyrodę. Dla mnie to stwierdzenie dotyczy jedynie nauki. A magia, którą reprezentuje szaman, to jedynie nasza niewiedza. On wykorzystuje takie techniki, których nie rozumiemy, dlatego wydają nam się obce i dziwne. Religia jest czymś innym. Ma większą moc. Ludzie wierzą i nie muszą doszukiwać się dowodów. Modlą się, a pod koniec życia czują strach przed Bogiem.

P.O.: W przypadku magii nie chodzi o niewiedzę, ale o niemożliwość wiedzy w ogóle. Wiedza ma granice, których nigdy się nie przekroczy. Nie ma, na przykład, wiedzy o przypadku (i być nie może) - mówił to Arystoteles. Jaka może być wiedza na temat zarażenia się wirusem w wyniku nieszczęśliwego przypadku? 
Żadna. Tylko rachunek prawdopodobieństwa, ale to ryzykującemu nic nie daje. Dlatego sięga po zaklęcie i amulet.

I magia, i religia posługują się tylko pseudodowodami. Gdyby wiary można było dowieść, stałaby się nauką (a gdyby można chociaż uzasadnić - wiedzą). Wierni tego nie oczekują, czerpią pewność z tradycji i autorytetów.

A jak rozumieć tezę „religia ma większą moc” (od magii)? Czy pewność śmierci ważniejsza dla ludzi niż niepewność losu? Raczej nie. Chodzi zapewne o to, że religia może łączyć się z moralnością, z sumieniem - i dlatego bywa tak ważna. Ale to przywilej jedynie wielkich religii soteriologicznych, religii zbawienia - jak chrześcijaństwo, buddyzm czy tradycyjne wiary Chin. W magii natomiast nie ma pojęcia czci i moralność się nie pojawia w ogóle, magia jest czysto instrumentalna. (W twórczości fantasy są „białe i czarne Gandalfy”, ale to w istocie kapłani i czarownicy jednocześnie).

Aleksandra Walczak pisze: Połowom ryb w lagunie, gdzie nie grozi niebezpieczeństwo, nie towarzyszy magia, bo są tam warunki, nad którymi człowiek może zapanować; połowom na otwartym morzu towarzyszy zaś magia - bo bywają tam warunki nieprzewidywalne, nad którymi nie da się zapanować. Niezwykle ciekawe badania i spostrzeżenia. Plemię pierwotne osiągnęło wiele dzięki umysłowi, doświadczeniu, wnioskowaniu, i stosuje magię nie po to, aby ona „załatwiła" za nich wszystko, tylko po to, aby zapewnić sobie pomyślność i bezpieczeństwo, ich poczucie. Magia jest niezwykle ważnym aspektem plemiennego życia, ale odnoszę wrażenie, że jest pewnego rodzaju tłem, a nie elementem głównym. W wypadku działań wojennych magia jest odprawiana, aby zapanować nad czynnikiem przypadku i szczęścia.

P.O.: Raczej: nieszczęścia (choć jedno łączy się z drugim). W warunkach normalnych wystarcza ludziom do działań nabyta wiedza. W sytuacjach (z gruntu, zawsze) nieprzewidywalnych uciekają się do magii - żeby zapanować (tylko psychologicznie, nie realnie) nad nieszczęśliwym przypadkiem. To „działalność zastępcza" - mówi Malinowski - ale ludziom niezbędna.

Anna Żeromska: Nie wiem, co oznacza „uciekanie do magii”. Wątpię, że ludzie w trudnych sytuacjach uciekają się do magii. Dla mnie to absurd... 
P.O.: To widocznie Pani jest wyjątkowo „antymagiczna”, tacy ludzie się zdarzają. Choć bardzo w to wątpię, czy rzeczywiście brak u Pani skłonności do horoskopów, parapsychologii czy „pozytywnego myślenia”, choćby.

Joanna Gólczyńska mówi: [...] Społeczności pierwotne dysponują wiedzą opartą na doświadczeniu (autorzy argumentują, podając przykłady plemion, które racjonalnie doskonalą swoje uprawy, połowy etc.). Chociaż ludzie ci są przekonani, że magia jest nieodzowna, mają odpowiednią wiedzę i doświadczenie i je wykorzystują, nie liczą, że sama magia ich „wyżywi”. Magię stosują w celu zapobiegania niepomyślnym warunkom, na które człowiek nie ma wpływu. Społeczności pierwotne dysponują początkami nauki.

P.O.: Tak jest.

I dalej, ta sama autorka pisze: Związek między magią a doświadczeniem: magia zrodziła się w poczuciu bezsilności i chęci działania - pojawia się wtedy działalność zastępcza (słowa, gesty, rytuały), pozwalająca na upust napięcia, dająca nadzieję, człowiek odzyskuje równowagę wewnętrzną. Ma przeświadczenie, że osiągnął cel.

P.O.: Myślę, że człowiek ma wtedy przede wszystkim poczucie losu! W tym wartość magii. Bez tego miałby poczucie, że jest panem, kowalem losu. Takich dziś wielu, ludzi niebezpiecznie naiwnych. Jest to skutek działania nowych, laickich religii: wiary w to, że człowiek wszystko może. Wystarczy spojrzeć przez okno, co może...

Joanna Gólczyńska: Komentarz ten od razu skojarzył mi się z książką Mistrz i Małgorzata. Chodzi o fragment rozmowy Michała Aleksandrowicza Berlioza z Wolandem:

- [...] Ale niepokoi mnie następujące zagadnienie: skoro nie ma Boga, to kto kieruje życiem człowieka i w ogóle wszystkim, co się dzieje na świecie? - O tym wszystkim decyduje człowiek - Berlioz pospieszył z gniewną odpowiedzią na to, trzeba przyznać, niezupełnie jasne pytanie. [...]

- [...] Ten, który jeszcze niedawno sądził, że o czymś tam decyduje, spoczywa sobie w drewnianej skrzynce, a otoczenie, zdając sobie sprawę, że z leżącego 
żadnego pożytku mieć już nie będzie, spala go w specjalnym piecu. [...] Czy naprawdę uważa pan, że ten człowiek sam sobą pokierował? Czy nie słuszniej byłoby uznać, że pokierował nim ktoś zupełnie inny? - tu nieznajomy zaśmiał się dziwnie". [...]

I jeszcze, ta sama autorka pisze: Magia a religia: obie dają możliwość „ucieczki” z sytuacji, z której nie ma racjonalnego wyjścia. Obie znajdują oparcie w tradycji i działają w atmosferze cudowności i tabu. Religia jednak zakłada wiarę w duszę i opatrzność, a magia - w siłę sprawczą magii. Religia stanowi cel sam w sobie, a magia jest pośrednikiem do określonego celu. Religia jest niezwykle złożona (obejmuje cały świat zjawisk nadprzyrodzonych), magia nie jest. Religia jest powszechna, magia - elitarna.

P.O.: Magia nie jest elitarna, jest powszechna (tylko czarownik jest wybrańcem). Ale jest indywidualistyczna, nie ma wspólnoty czysto magicznej. (Wyjątkiem wspólnoty plemienne: one są zawsze religijne, ale mogą stosować magię kolektywnie - choćby dla sprowadzenia deszczu, dla wszystkich). Religia nie stanowi celu samego w sobie - ona stawia cele autonomiczne, duchowe. A magia - jedynie instrumentalne, życiowe, bez czci. Religie bywają niezwykle złożone, ale nie wszystkie (np. szamanizm). Magia jest w istocie działalnością prostą (choć w otoczce tajemniczości i niezwykłości). Religia natomiast nie musi zakładać wiary w duszę i opatrzność (np. chińska), ale zawsze zakłada - w siły osobowe czy moralne. Siły magiczne są zaś bezosobowe (włada nimi czarownik).

Emilia Staszewska zaś powiada: Przeczytawszy publikację, uważam, że magia stanowi pewnego rodzaju zabezpieczenie, zaufanie do sił nadprzyrodzonych, jest w pewnym stopniu zrzuceniem poczucia odpowiedzialności za powodzenia lub niepowodzenia, na przykład, upraw danego roku. Zawierzenie spraw doczesnych, obecne zarówno w magii, jak i religii, jest formą „przekazania zmartwienia”. Świadomość konieczności podjęcia środków zapobiegawczych zdaje się obecna w ludzkiej naturze, niezależnie od sfery życia, której dotyczy. Moim zdaniem nie jest to jednocześnie ani zrzucenie odpowiedzialności na siły nadprzyrodzone, ani zaufanie do własnej wiedzy, lecz stanowi narzędzie równowagi. Pozwala jednocześnie brać odpowiedzialność za swoją pracę, podejmowane decyzje i mieć poczucie opieki kogoś/czegoś silniejszego od nas, nad ludzkimi problemami. Po- 
dejście Melanezyjczyków do magii, utwierdza mnie w takim przekonaniu, wykorzystywanie przez nich magii pokazuje, że zrzucają ze swoich barków odpowiedzialność za swoje czyny, widząc przyczynę choroby lub złego samopoczucia w zesłanym przez magię stanie, który ich dotknął.

P.O.: Nie sądzę, by chodziło o „zrzucenie odpowiedzialności”. Kto czuje odpowiedzialność za tajfun? Chodzi o poczucie losu, o ułożenie się człowieka z losem, o jakiś modus vivendi (sposób) na los. Ponieważ mamy rozum, musimy stosunek do losu wypracować. Zawsze.

Agnieszka Topolińska stwierdza: Każda społeczność pierwotna dysponuje znacznym zasobem wiedzy opartej na doświadczeniu i ukształtowanej przez rozum. Ale odprawia też magię, aby zapanować nad czynnikiem przypadku i szczęścia. Człowiek pierwotny wie, że sadzonka nie może urosnąć dzięki samej magii ani czółno żeglować, czy płynąć, jeśli nie będzie właściwie zbudowane i kierowane, wie też, że nie można wygrać bitwy, jeśli nie ma umiejętności i odwagi.

P.O.: Otóż to.

I dalej mówi ta sama autorka: Sztuka magiczna jest więc skierowana na realizację celów praktycznych. Podstawą magii jest specyficzne przeżywanie stanów emocjonalnych, w których człowiek obserwuje nie przyrodę, lecz samego siebie, w których prawdę poznaje nie przez rozum, lecz poprzez grę uczuć we własnym organizmie. Magia opiera się na wierze, że nadzieja nie może zawieść, a pragnienie oszukać. Magia akcentuje wyższość ufności nad zwątpieniem, nieugiętości nad wahaniem, optymizmu nad pesymizmem. Wiara religijna zaś kształtuje, utrwala i uwydatnia wszelkie cenne podstawy umysłu, takie jak szacunek dla tradycji, zgodne współistnienie ze środowiskiem, odwaga i ufność $\mathrm{w}$ walce $\mathrm{z}$ trudnościami i w obliczu śmierci.

P.O.: To chyba nazbyt egzaltowana wypowiedź. Co to znaczy „poznawać prawdę przez grę uczuć"? Prawdę o czym? Magia to nie jest otumanianie. To raczej trzeźwe a rozpaczliwe gesty płynące z ludzkiej bezradności, ale dające poczucie losu, a przez to i jakiś hart ducha. Religia natomiast nie zawsze „kształtuje cenne podstawy umysłu". To wiadomo. 
Ta sama autorka konkluduje: Moim zdaniem Malinowski ma dużo racji. Człowiek trwa zawsze przy magii, gdy się przekonuje, że jego wiedza i techniki racjonalne są bezsilne. Magia jest oparta na czynnikach psychicznych i emocjonalnych. Myślę, że w naturze człowieka tkwi wiara w magię i mistyczną energię. W dzisiejszych czasach wielu ludzi wierzy w magię, ale inni stanowczo zaprzeczają jej istnieniu. Magia została spopularyzowana w tekstach kultury i jest przedstawiona zazwyczaj pozytywnie. Aspekt magii w literaturze moim zdaniem jest nieszkodliwy i bardzo ciekawy. Wiele osób wierzących uważa zaś, że jest on niedopuszczalny i jest pewnego rodzaju bluźnierstwem czy grzechem. Ale ja myślę, że jest to jedynie fikcja literacka, która nie jest w żaden sposób szkodliwa. Magia, jak i religia są obie duchowymi formami wierzeń. Nikt tak naprawdę nie wie, czy one istnieją, ale ludzie mimo to w nie wierzą.

P.O.: Jak to - nie wie? Wszyscy wiedzą, że magia i religia istnieją. Tylko nie wszyscy zgadzają się z ich treściami. A jeszcze mniej ludzi rozumie ich istotę. A co do szkodliwości magii - we właściwych proporcjach szkodliwa nie jest (np. odpukiwanie w niemalowane), a nawet pożyteczna - co głosił Malinowski. Nadmiar magii jest natomiast szkodliwy, jej dominacja, wkraczanie na teren wiedzy i religii. Nie dziwię się, że ludzie religijni protestują, kiedy widzą dzieci i młodzież pogrążone głównie w literaturze o czarownikach. Taka literatura, bez przeciwwagi, psuje umysł - wpaja fałszywy obraz świata, że „czarodzieje mogą wszystko”. Nie mogą, nikt z nas nie może. I tego uczą tradycyjne wielkie religie.

Agnieszka Topolińska: Protest ludzi religijnych w stosunku do literatury młodzieżowej o tematyce magicznej bardzo mnie zaskakuje i szczerze mówiąc, nie rozumiem go. To jest fikcja i nie uważam, żeby było to szkodliwe dla dzieci czytających taką literaturę. Potrafią one oddzielić świat fikcyjny od rzeczywistego. Jeżeli ludzie religijni nie wierzą w magię, to dlaczego protestują? Przywołując sytuację palenia takich książek i innych przedmiotów „magicznych” w jednej z gdańskich parafii w zeszłym roku, uważam, że jest to zabobonne podejście do religii i paradoksalnie współuczestniczenie w tym, z czym się walczy. Bo czy to przypadkiem nie magia właśnie przypisuje ponadnaturalne działanie przedmiotom? Chrześcijaństwo przyniosło światu wolność od bycia zależnym od dobrych i złych bogów oraz ich kaprysów, pokazało Boga, który nie zsyła cierpienia na zasadzie „bo tak”, ale oferuje miłość. Palenie książek to krok w przeciwną stronę 
i uznanie, że istnieją przedmioty, które mogą na nas wpływać nawet wtedy, kiedy tego nie chcemy.

P.O.: Istnieją przedmioty, czy raczej zjawiska, które na nas źle wpływają. To jasne. Wpływają nie magicznie, lecz realnie. Fikcje do nich należą, choćby fikcje reklamy czy ideologii politycznych. Dzieci szczególnie są na nie podatne. Nie ma się co dziwić, że w imię moralności groźne fikcje się tępi. Natomiast palenie książek, w tym punkcie zgoda, zawsze jest barbarzyństwem. Ludzie cywilizowani ze słowem walczą słowem, a nie rękami. Nie licząc publicznych słów ordynarnych i kłamliwych - ludźmi rzucającymi takie ma zająć się sąd.

Agata Mrowińska pisze: Prowadząc rozważania nad magią, autor mówi, że ona zawsze była, niepotrzebne są obserwacje, by ją tworzyć, lecz aby ją poznać, niezbędna jest tradycja. Patrząc od strony socjologiczno-psychologicznej, autor mówi o działaniu zastępczym, które pojawia się u człowieka, kiedy zostanie zatrzymany w działaniu przez nieprzewidywalne nigdy sytuacje. Wtedy dzięki gestom i słowom odzyskuje wewnętrzną równowagę, przeklina rzeczywistość, modli się, wierzy, błaga. Tu od razu nachodzi mnie refleksja na temat tego, że człowiek, kiedy utraci wiarę w rozum, w naukę, kiedy jest w kryzysie czy w ogromnej euforii, zwraca się w stronę religii i magii, wtedy jakoś głębiej odkrywa stronę świętości. I tu zadaję sobie pytanie: czy wtedy religia i magia są jedynie wytworem emocjonalnym? Bo człowiek myśli, że zapełnił wewnętrzną pustkę, bo ucieka do sfery sacrum, bo szuka rozwiązania. Czy te okresy słabości lub euforii są jedynie po to, aby nie zapominał on o tej części świata i człowieczeństwa, a to wszystko tak naprawdę dzieje się poza człowiekiem? Wiem, że tak jak mówi autor, religia i magia nie biorą się z powietrza, jednak zastanawiam się, czy jest możliwość, żeby był to jedynie wytwór psychiki, który objawia się w najbardziej emocjonalnych momentach? Czy rzeczywiście jest niezależną częścią człowieka, czy też pochodzi z zewnątrz?

P.O.: To, co już wyżej zostało powiedziane, daje odpowiedź. Nie chodzi o „chwile słabości”, ale o słabość jakąś rdzenną kondycji ludzkiej. Nie chodzi o „utratę wiary w rozum", tylko o świadomość, że rozum ma granice, że sama wiedza nie wystarcza. To rozumne: znać granice rozumu, nieprzekraczalne. Magia i religia nie są subiektywnymi wytworami psychiki, ale „pochodzą z zewnątrz”, tzn. taki 
jest mechanizm świata i taka konstrukcja człowieka (obiektywnie), że magia i religia pojawiają się w życiu społecznym. Tak było, jest i będzie. Tylko formy się zmieniają, jak ludzkich ubiorów.

Małgorzata Sieńkowska powiada: „Człowieka dzikiego” rozumiem jako człowieka sprzed cywilizacji nowoczesnej. Wtedy jedynym zmartwieniem było zdobycie pokarmu i przeżycie w otaczającym świecie. Taki człowiek nie miał czasu na rozmyślania, lecz na planowanie zdobycia jedzenia, własnej ochrony i ochrony swojej rodziny. Rozmyślanie zaczęło się w momencie, kiedy człowiek przestał wędrować i zaczął się osiedlać. Zaczął budować cywilizację i pierwsze państwa. Wtedy człowiek przestawał się martwić (na większą skalę) o przeżycie.

P.O.: Myślę, że to nieprawda. „Dziki” to nie znaczy „bez cywilizacji nowoczesnej”, ale „bez jakiejkolwiek” (bez państw, wojen, pisma, wyrafinowanej kultury); człowiek żyjący w plemieniu zbieracko-łowieckim, niczym w paleolicie. Ale nieprawda, że w paleolicie jedynym zmartwieniem było jedzenie: była rodzina, więc i miłość, i głęboki wstyd (nie ma na ówczesnych malowidłach żadnych aktów płciowych), i groby były, i sztuka - cele więc autonomiczne i wielkie. I był czas na wszystko. Kiedy człowiek się osiedlił (rolnictwo), to przestało mu się wielkich rzeczy chcieć, zgnuśniał - bo miał niemal zawsze jedzenie. Nie ma wielkiej sztuki neolitu, a paleolitu jest. Dopiero od czasu państw (cywilizacji), czyli ok. 6 tys. lat, wielkie cele powróciły. Ale nie z powodu braku zmartwień, tylko przeciwnie duchowych zmartwień nowego typu.

I jeszcze czytamy u tej samej autorki: Dopiero później, gdy człowiek przestał wędrować, nauka zyskała wyższe miejsce od magii. Jednak obydwie te dziedziny współgrały ze sobą od zawsze i nadal to robią. Każdy z nas bowiem wierzy w choćby maleńki przesąd i każdy z nas opiera swoją wiedzę na nauce.

P.O.: To prawda - każdy. Natomiast nigdy „nauka nie zyskała wyższego miejsca od magii”. Może tylko w cywilizacji naszej, Zachodniej. Dzięki negatywnemu stosunkowi chrześcijaństwa do magii w ciągu kilku wieków (XVII-XIX?) magia została zepchnięta na drugi plan, poza wielką kulturę (stała się gminna). Wcześniej przecież pełno było astrologii i alchemii, a od XIX w. do dziś - okultyzmu (parapsychologie, paramedycyny itp.). Mamy renesans magii, tylko wrażenie po- 
zostało, że nauka stoi wyżej. Dla większości współczesnych ta prawdziwa nauka (wyższa matematyka, fizyka kwantowa, genetyka) jest za trudna i w ich oczach nie różni się zbytnio od magii. Obie są tajemnicze i „cudowne”.

Aleksandra Dąbrowska: Wydaje mi się, że faktycznie mamy do czynienia z renesansem magii. Wiele osób regularnie chodzi do wróżek, czyta horoskopy i naprawdę w nie wierzy. Łatwiej wierzyć bowiem w magię, niż ogarniać naukę. Łatwiej o nadzieję pokładaną w magii niż o optymistyczne patrzenie w przyszłość na podstawie danych nauki.

Anna Żeromska zaś mówi: Odnosząc się do dobra i zła, myślę, że nie ma dobra i zła, a są czyny człowieka moralne i niemoralne. Rozumiem, że część osób, tak jak wspomniano w tekście, chodzi do kościoła „na pokaz”, bo sąsiedzi idą itd. Zgrywają świętych i poczciwych, a nie potrafią pomóc bliźniemu w potrzebie. Tacy ludzie raczej nie rozumieją, po co w ich życiu jest religia, i raczej się to nie zmieni, bo skoro chodzą co niedzielę do kościoła i słuchają kazań, a nie wyciągają z nich wniosków, to nic nie zmienia się w ich życiu.

Dość istotne jest to, by ludzie znali też inne religie i potrafili je zrozumieć na tyle, by nie wywoływać $\mathrm{z}$ ich powodu wojny.

P.O.: A czym się różni dobro i zło od czynów moralnych i niemoralnych? Albo jesteśmy absolutystami i wówczas niczym, albo relatywistami - i wówczas też niczym. Są czyny, które zawsze należy spełniać, i takie, których nigdy nie wolno (np. gwałcić dzieci, mordować niewinnych, jeść trupów - bo to zło). Relatywiści zaś uważają, że nie ma takich czynów; ocena czynu zależy zawsze od społeczeństwa. Ci zaś, co „chodzą do kościoła na pokaz” i „nie wyciągają wniosków z kazań”, czy bez chodzenia byliby lepsi? Wątpię. Myślę, że nawet gorsi, bo choćby wstyd przed księdzem i parafianami coś daje, jakoś hamuje wstrętne popędy. Skąd przekonanie, że nic się w duszy „od chodzenia do kościoła” nie zmienia? To nieuzasadnione.

Nie ma to nic wspólnego z rozumieniem religii. Rozumienie to sprawa intelektu, a nie moralności. My się tu i teraz, na UW, zajmujemy tylko rozumieniem, nie moralnością czy pobożnością.

I sprawa ostatnia. „Rozumienie” innych religii nic nie daje w kwestii unikania wojen. Straszliwe wojny toczyli chrześcijanie, nawet katolicy, między sobą, ro- 
zumiejąc się. A czy studiując 30 lat Koran, wyzbędę się poczucia jego obcości? A nawet szpetności? Przeciwnie. Wojnom można zapobiegać tylko politycznie.

Anna Żeromska: Tak, zgadzam się, że ocena zależy od społeczeństwa. Nie wiem, jacy ludzie byliby, gdyby do kościoła nie chodzili, nie jestem w stanie powiedzieć, bo to zależy od każdej osoby, od jej osobowości.

P.O.: Pani się zgadza z relatywistami, ale nie ze mną ani nie z Tatarkiewiczem, Elzenbergiem, Miłoszem („istnieje dobro i zło”), i nie z Lemem. Nie wierzy Pani w sumienie? Uznaje Pani, że kompas działa na podstawie obiektywnie istniejąceych biegunów magnetycznych Ziemi, a ludzka busola moralna (tj. sumienie) - w oparciu na arbitralnie ustanowionych „biegunach moralnych”? To dlaczego w każdej epoce i w każdej społeczności ludzie podobnie reagują na gwałcenie dzieci czy bezczeszczenie zwłok? Sokrates mówił, że dajmonion (taki duch czy głos bóstwa) podpowiada każdemu, czego robić nie wolno. To samo podpowiadał Grekom, a później chrześcijanom i Indianom, i wszystkim innym, od kromaniończyków poczynając. A że nie wszyscy się stosują, to już inna rzecz, jak Pani mówi: „to zależy od osobowości”. I od okoliczności (interesy, wierzenia, wpływ innych). Można wierzyć, że denuncjowanie ludzi jest słuszne, choć sumienie mówi co innego. Więc to, co się w Kościele gada, nie jest bez znaczenia dla realizowania głosu dajmoniona.

Agata Mrowińska: W nawiązaniu do wiary i niewiary, autor Ziemi Ulro pisze, że może decyzja pójścia do kościoła z powinności jest dla obdarzonego ogromnym poczuciem humoru (jak mówi) Pana Boga dostatecznym aktem wiary. Ja początkowo pomyślałam, że nie może to być prawdą, bo jaki sens ma praktyka bez wiary? Można by ją przyrównywać do codziennych, nic dla naszych dusz nieznaczących, czynności, jak np. mycie zębów. Jednak po namyśle doszłam do wniosku, że sam obrzęd, który zbliża człowieka, nawet nieświadomie, do Boga, sakrament, który łączy bezpośrednio z Bogiem, bez względu na wszystko, musi mieć znaczenie dla duszy człowieka, nieważne, czym jest motywowany. Może tylko pozornie jest to dla takiej osoby powierzchowna rutyna. Praktyka religijna, nawet podświadomie, oddziałuje na człowieka i wywiera wpływ na jego postępowanie, choćby nawet był niewierzący. Obrzędy też są częścią religii. 
P.O.: Religioznawcy mówią, że najważniejszą częścią. Od obrzędów zaczęła się religia, w paleolicie. Nie było jeszcze mitologii.

Agata Mrowińska: Czesław Miłosz podkreśla wyraźnie, że istnieje dobro i zło, i nie są to wartości względne. Myślę, że wielu ludziom ciężko jest to przyjąć i zrozumieć, szukają czegoś łatwiejszego. Może jest to jeden z powodów poszukiwania coraz to nowszych form religii, idei wyjaśniających powstanie świata i bezkrytycznego przyjmowania różnych „filozoficznych dań”. Może też z tego powodu praktykują daną religię, mimo że jej do końca nie rozumieją, bo nie rozumieją bezwzględności wartości, a podświadomie dążą do odkrycia prawdy. Wewnętrznie boją się, że nie kultywując religii, coś tracą.

P.O.: Dziękuję Paniom za owocną dyskusję. W trzech grupach studentów w Instytucie Filozofii UW nie udało mi się takiej dyskusji przeprowadzić.

Warszawa, 5-26.05.2020. 